\title{
MEDICAL STUDENTS' PHYSICAL ACTIVITY AS AN INDICATOR OF THEIR COMMITMENT TO HEALTHY LIFESTYLE
}

levleva OV

Pirogov Russian National Research Medical University, Moscow, Russia

Physicians, who provide general medical services, should give the patients an advice on physical activity. The study was aimed to assess physical activity of medical students, as well as their awareness of this issue, and willingness to provide the public an advice on commitment to a healthy lifestyle in terms of physical activity. A total of 518 medical students were surveyed. The data obtained with the Steps and Screen Time mobile applications were used. Physical fitness was assessed using the standard anthropometric technique. Statisctical processing of the data obtained was performed with the Statistica 13 PL statistical software package. The study met the requirements of biomedical ethics and posed no risk to participants. No significant differences in the number of steps between males and females was observed. It was $9033 \pm 3297$ steps in males and $7807 \pm 3570$ steps in females. The evidence supporting the relationship between physical activity and average time spent on a smartphone per day was obtained: the correlation coefficient for the relationship between the number of steps per day and the screen time was -0.36 (moderate negative correlation). Correlation coefficients for the relationships between body mass index and physical activity $(-0.35)$ and between body mass index and screen time ( 0.33 , moderate positive correlation) were calculated. The data obtained allowed us to develop simple and feasible guidelines on improving physical activity in medical students, as well as to develop a tracker of positive habit of daily optimal physical activity for each student, and to discuss the results within the framework of the business game Physical Activity in Various Sectors of Population.

Keywords: students, electronic devices, motor activity

Author contribution: levleva OV — literature analysis, study design, data acquisition, statistical analysis, manuscript writing.

Compliance with ethical standards: the study was approved by the Ethics Committee of the Pirogov Russian National Research Medical University (protocol No. 203 dated December 20, 2020). The informed consent was obtained from all participants. Online survey was conducted on a voluntary basis using the online service. The study met the requirements of biomedical ethics and posed no risk to participants.

$\square$ Correspondence should be addressed: Olga V. levleva

Ostrovitianov str. 1, Moscow, 117997; cool-iev@ya.ru

Received: 12.05.221 Accepted:: 14.05.2021 Published online:: 29.06.2021

DOI: $10.24075 /$ rbh.2021.009

\section{ДВИГАТЕЛЬНАЯ АКТИВНОСТЬ СТУДЕНТОВ-МЕДИКОВ КАК ИНДИКАТОР ИХ ПРИВЕРЖЕННОСТИ ЗДОРОВОМУ ОБРАЗУ ЖИЗНИ}

\section{О. В. Иевлева}

Российский национальный исследовательский медицинский университет им. Н.И. Пирогова, Москва, Россия

\begin{abstract}
Врачам, в рамках первичной медико-санитарной помощи, необходимо предоставлять пациентам консультации по физической активности. Цель работы: изучить двигательную активность студентов-медиков и их информированность по данному вопросу, а также готовность к консультированию населения по вопросам приверженности здоровому образу жизни в части двигательной активности. Опрошены 518 студентов-медиков, использованы данные приложений для смартфонов «Шаги» и «Экранное время», проведено изучение физического развития с помощью стандартной антропометрической методики. Статистическая обработка полученных данных проводилась с использованием пакета статистического анализа Statistica 13 PL. Исследование соответствовало требованиям биомедицинской этики и не подвергало опасности участников. Среднее количество шагов у юношей и девушек не имеет

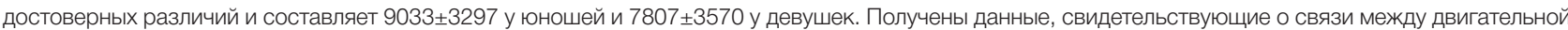
активностью и средним временем использования смартфона в день - коэффициент корреляции между количеством шагов в день и «экранным временем» отрицательный средней силы -0,36, рассчитаны коэффиициент корреляции между индексом массы тела и двигательной активностью $(-0,35)$ и между индексом массы тела и «экранцным» временем, который положительный, средней силы 0,33. Полученные данные позволили сформулировать простые, выполнимые рекомендации по повышению двигательной активности студентов-медиков и ссрормировать для каждого трекеры привычек по формированию «полезной» привычки к ежедневной оптимальной двигательной активности и обсудить результаты в рамках деловой игры по теме «Двигательная активность для различных групп населения».
\end{abstract}

Ключевые слова: студенты, электронные устройства, двигательная активность

Вклад автора: Иевлева О.В.- анализ литературы, дизайн исследования, сбор материала, статистическая обработка, написание статьи.

Соблюдение этических стандартов: Данное исследование было одобрено ЛЭК РНИМУ им. Н.И. Пирогова (Протокол № 203 от 20.12 .2020 года). Добровольное информированное согласие было получено для каждого участника. Онлайн-опрос проводился надобровольной основе с использованием онлайн-сервиса. Исследование соответствовало требованиям биомедицинской этики и не подвергало опасности участников.

$\bowtie$ Для корреспонденции: Иевлева Ольга Владимировна ул. Островитянова, д. 1, г. Москва, 117997; cool-ievl@уa.ru

Поступила: 12.05.2021 Статья принята к печати: 14.05.2021 Опубликована онлайн: 29.06.2021

DOI: $10.24075 /$ rbh.2021.009

Over the past decade, the studies are being regularly published in scientific literature, which report low physical activity levels in medical students, the future doctors. This poses a direct risk to their health and can affect their future work with patients (community) in terms of obtaining a commitment to a healthy lifestyle $[1,2,3,4]$.
Moreover, physical inactivity in children, adolescents and youth is closely related to the problem of overweight and obesity [5].

Moreover, physicians, who provide general medical services, should give the patients an advice on physical activity. However, training on providing advice on physical activity is often under- 
reported in the curriculum of medical schools. It is unclear whether medical students are ready to provide effective consultation in this area [6-9].

The study was aimed to assess physical activity of medical students, as well as their awareness of this issue, and willingness to provide an advice on commitment to a healthy lifestyle in terms of physical activity to the public.

\section{METHODS}

To attain the goals established, specialists of the Hygiene Department of Pediatric Faculty of the Pirogov Russian National Research Medical University, holding certificates of "Hygienic Education", "Epidemiology", "Hygiene of Children and Adolescents", and "General Hygiene", developed a questionnaire for assessment of the medical students' lifestyle hosted on Google Forms [10].

The questionnaires proposed to respondents contained a small section with personal data and a number of evaluative questions beginning with "Please assess the risk to your health...". These questions reflected subjective evaluation of the impact of the factors affecting health. The risk posed by exposure to each studied factor was rated on a scale of 0 to 10 .

The study design consisted in evaluation of the medical students awareness of risk to health posed by lack of physical activity, investigation of the medical students' commitment to a healthy lifestyle in terms of physical activity, search for the proof of physical inactivity effects on health, as well as defining the medical students' willingness to change their lifestyle, and to work with the patients (community) in this area in the future (Fig. 1).

A total of 518 medical students were surveyed, of them $80 \%$ were girls. The average age of the students surveyed $(M \pm m)$ was $20.1 \pm 0.08$ years.

We also used data of the Steps (average number of steps per day) and Screen Time (average time of using smartphone per day) mobile applications.

Physical fitness of medical students was assessed using the standard anthropometric technique [8, 11-13].

Statistical processing of the results was performed using the Statistica 13 PL software package (StatSoft, USA). Descriptive statistics was used: mean values, standard error of the mean, and standard deviation were calculated. Distribution of indicators was tested for normality using the Kolmogorov-Smirnov normality test; asymmetry and kurtosis as well as their their standard errors were analyzed.

The significance of differences was estimated using the Student's t-test. The differences were considered significant when $t \geq 2.0-(p<0.05), t \geq 2.6-(p<0.01), t \geq 3.3-(p<0.001)$.

Correlation between the studied parameters was considered strong when $r=0.7-1.0$, moderate when $r=0.3-0.699$, and weak when $r=0-0,299$ [5].

The Statistica 13 PL software package (StatSoft, USA) was used.

The study did not violate human rights and endanger the respondents. The study met the requirements of biomedical ethics and was approved by the Ethics Committee of the
Pirogov Russian National Research Medical University (protocol No. 203 dated December 20, 2020) in accordance with the GCP principles. The informed consent was obtained from all participants. The online survey was conducted on a voluntary basis using the online service. All the studies were conducted in accordance with ethical norms set out in the Declaration of Helsinki and the European Union directives (8/609EC).

\section{RESULTS}

The medical students subjectively considered the risk to their health posed by lack of physical activity as relatively high. They assigned it the average $(\mathrm{M} \pm \mathrm{m})$ score of $8.5 \pm 0.3$ out of 10. The group of students who underestimated the risk was only $8.0 \%$, i.e. the future doctors were aware of the adverse effects of physical inactivity on health. A total of $50.4 \%$ surveyed medical students considered their levels of physical activity as insufficient. Among the persons surveyed, 50.0\% pointed out that that they preferred active leisure activities (sports, dancing, walking), and the other $50.0 \%$ noted that they preferred passive leisure activities (social networking, watching movies, reading, playing computer games); $46.8 \%$ of surveyed medical students reported no increase in physical activity during weekends.

During the study, the number of steps per day was used as an objective measure for describing physical activity. Researchers used primarily pedometers and similar devices for measurement of this parameter in the past. During our study the number of steps per day was defined using the Steps mobile application, because $99.5 \%$ of surveyed students used different models of smartphones, and $66.6 \%$ surveyed students rarely weaned themselves off the electronic devices, never lost their electronic devices, continuously monitored notifications on their electronic devices, etc. The other $31.3 \%$ monitored notifications on their electronic devices every hour.

Distribution of the indicator in the population is an important means for describing the indicator. The Kolmogorov-Smirnov normality test confirmed the hypothesis of normal distribution for the medical students' physical activity parameter measured in steps per day, since the significance level was $p \geq 0.20$. The average $(M \pm \sigma)$ number of steps showed no significant differences between males and females ( $p \geq 0.05)$. It was $9033 \pm 3297$ in males and $7807 \pm 3570$ in females. Thus, the average physical activity of male students was $5736-12,330$ steps per day, and in female students it was 4237-11,314 steps per day respectively (Fig. 2).

According to the Tudor-Locke physical activity classification, limited physical activity intensity (2500-4999 steps per day) was observed in $6.0 \%$ of medical students, low physical activity intensity (5000-7499 steps per day) was observed in 16.0\%, and the intensity of physical activity lower than average (7500-9999 steps per day) was observed in $32.0 \%$. Moderate intensity of physical activity (10000-12499 steps per day) was observed only in $36.0 \%$ of medical students, and high physical activity intensity (12500 and more steps per day) was observed only in $10.0 \%$. Thus, based on objective evidence, only $46.0 \%$ of medical students demonstrated commitment to the principles of the a healthy lifestule in reality, which showed reasonable

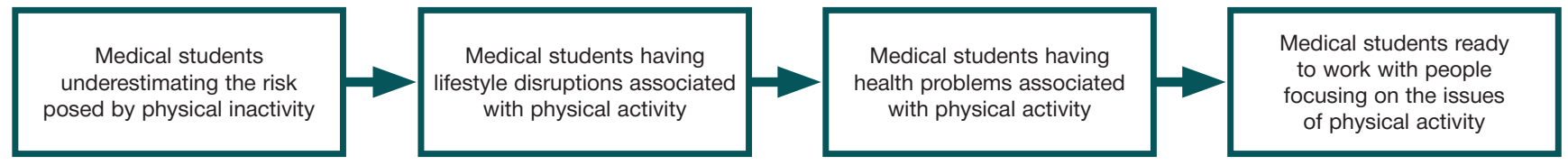

Fig. 1. Study design 


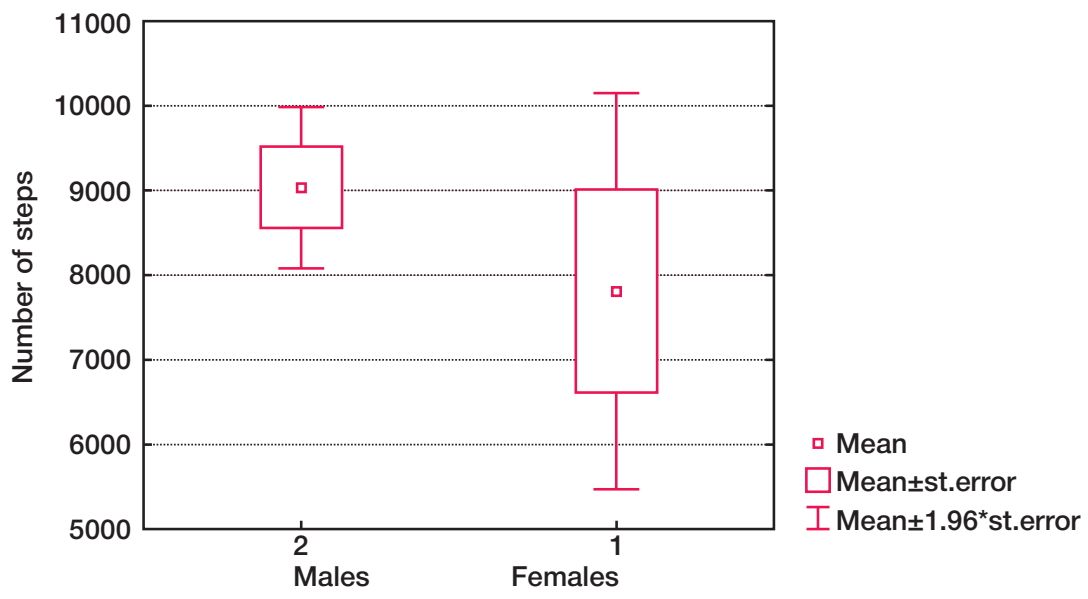

Fig. 2. Physical activity per day (steps) in male and female students

agreement with the surveyed medical students' subjective considerations.

Results of the physical activity assessment showed that the average $(\mathrm{M} \pm \mathrm{m})$ height of male students was $178.4 \pm 0.9 \mathrm{~cm}$, and in female students it was $166.8 \pm 0.8 \mathrm{~cm}$; the average body weight was $72.2 \pm 1.3 \mathrm{~kg}$ and $56.9 \pm 1.2 \mathrm{~kg}$; the average body mass index was $22.5 \pm 0.3 \mathrm{~kg} / \mathrm{m} 2$ and $20.4 \pm 0.3 \mathrm{~kg} / \mathrm{m} 2$ respectively $(\mathrm{p} \leq 0.05)$. Obesity of various degree was observed in $10.1 \%$ of the examined medical students. However, only $2.9 \%$ of them believed they had health problems. Probably, the interviewed persons underestimated the significance of overweight and obesity. Then the data demonstrating the relationship between physical activity and average time spent on a smartphone per day were obtained, the correlation coefficient for the relationship between the number of steps per day and "screen time" of -0.36 (moderate negative correlation). Correlation coefficients for relationships between body mass index and physical activity $(-0.35$, moderate negative correlation) and between body mass index and and "screen time" (0.33, moderate positive correlation) were calculated.

The average $(\mathrm{M} \pm \mathrm{m})$ values of the right and left hand muscle strength, which were dependent on physical activity levels, were low: $38.1 \pm 0.2$ and $37.1 \pm 0.3 \mathrm{~kg}$ in males, $18.9 \pm 0.3$ and $16.7 \pm 0.3 \mathrm{~kg}$ in females ( $\mathrm{p} \leq 0.05)$. Since the vast majority of medical students rarely weaned themselves off the smartphones, the time spent on a smartphone was analyzed using the data obtained from the Screen Time application. According to the Screen Time application data, the average $(\mathrm{M} \pm \sigma)$ time spent on a smartphone was $336.4 \pm 15$ minutes per day, i.e. about 5.6 hours during the ordinary academic day. Correlation coefficient for the relationship between muscle strength and screen time was also calculated $(-0.31$, moderate negative correlation).

Thus, modern medical students spend considerable time working with their smartphones, which has a negative impact on the levels of physical activity and physical fitness indicators in males and females.

The surveyed medical students gave their commitment to principles of healthy lifestyle an average $(\mathrm{M} \pm \mathrm{m})$ subjective ranking of $6.2 \pm 0.2$ out of 10 . Furthermore, $18.8 \%$ of surveyed students did not consider themselves to commit to principles of healthy lifestyle, and $7.5 \%$ had no interest in healthy lifestyle. About $40.2 \%$ of students reported that they were careful about their levels of physical activity. The others were likely to underestimate the significance of this protective factor.

The surveyed medical students noted that they used some Health applications on their smartphones: $70.8 \%$ had installed appropriate applications and sometimes browsed the data of monitoring heart rate, BMl, etc; $55.4 \%$ used the Screen Time application, 22.0\% used the Steps application, and the others used nothing. The majority of medical students (83.3\%) reported they obtained relevant information on healthy lifestyle from Internet sources. However, $88.2 \%$ of medical students reported no subscriptions to any resources on healthy lifestyle provided by medical institutions, working in prevention with the public (such as Centre of Hygienic Education of People of Rospotrebnadzor and other). Thus, there is some inconsistency; this also poses the question, which Internet resources are used by students to obtain information on healthy lifestyle.

The surveyed medical students ranked their willingness to provide an advice on commitment to a healthy lifestyle in terms of physical activity to patients (community) as relatively low: an average $(\mathrm{M} \pm \mathrm{m})$ of $5.6 \pm 0.3$ points out of 10 . Moreover, $48.2 \%$ of students believed they were not prepared to this kind of activity.

The study results demonstrate that medical students rank their commitment to a healthy lifestyle and their physical activity based mainly on the subjective assessment, without supporting it with objective criteria, such as data of health applications for smartphone, data on body's functional status, no diagnoses, etc. It can be assumed that junior high school students have insufficient motivation to optimize their physical activity, being a powerful preventive factor possessing a health protection effect. They also have no essential motivation skills, as well as no access points to relevant information on this issue. Only about $50.0 \%$ of all surveyed medical students considered themselves as advocates for commitment to a healthy lifestyle for patients and community, including leading by example.

\section{DISCUSSION}

Models of physical activity and healthy lifestyle acquired during childhood and adolescence remain throughout the later life. Therefore, for the future health of the whole population it is essential to improve the levels of physical activity in young people $[1,4,9,13,14]$.

Many factors interfere with increasing physical activity in young people:

- lack of time;

- low motivation;

- lack of support and guidance;

- feeling uneasy and incapable;

- lack of safe place for excercise; 
- limited access to places and equipment for physical activity;

- lack of knowledge about the benefits of physical activity.

The studies have been published on investigation of physical activity and its relationship to improved health. These studies demonstrate positive correlation between physical activity and improved health of the subjects [4, 9, 14-17].

Therefore, there is a need for development of physical activity training programs, as well as public health programs aimed at improving the relevance of physical activity for the public $[18,19]$.

Shaping and development of knowledge and skills related to physical activity would be instrumental in addressing the issues both of medical students health improvement and quality preventive work with the patients. However, this challenge should be first met at the university level, where the principles of universal competence UC-7 (health protection) and general professional competence GPC-2 (healthy lifestyle) are developed in medical students [17-19].

It is essential to provide the future doctors training on principles of healthy lifestyle during studying at medical schools. This is important based on the results of the studies, which demonstrate reduced number of students with healthy lifestyle after graduation [20-24].

\section{CONCLUSION}

In the process of medical schooling it is essential to aim for the target of at least $60.0 \%$ of medical students with optimum levels of physical activity.

The data obtained during the study allowed us to develop simple and feasible guidelines on improving physical activity in medical students:

1. Giving up the elevator in favor of the stairs.

2. Outdoor exercise (possibly combined with walking the dog) at least 30-40 minutes per day.

3. Housework, possibly combined with dancing.

4. Morning exercise, also with dance elements.

5. Walking with younger siblings, playing active games with them.

Each student should track the development of a positive habit of daily optimal physical activity. The results should be discussed within the framework of the business game Physical Activity in Various Sectors of Population.

\section{References}

1. Evdokimov VI, Gubina Ol.i dr. Metodika otsenki psikhicheskogo zdorov'ya i pokazateli adaptatsii studentov VGMA. Sistemnyy analiz i upravlenie v biomeditsinskikh sistemakh. 2005; 4 (4): 457-460. Russian.

2. Popov VI, Libina II, Gubina OI. Problemy sovershenstvovaniya i optimizatsii uchebnogo protsessa $\vee$ meditsinskom vuze. Zdorov'e - osnova chelovecheskogo potentsiala - problemy i puti ikh resheniya. 2010; 5 (1): 185-186. Russian.

3. Glybochko PV, Esaulenko IE i dr. Zdorov'e studentov meditsinskikh vuzov Rossii: problemy i puti ikh resheniya. Sechenovskiy vestnik. 2017; 2 (28): 4-11. Russian.

4. Blake H., Stanulewicz N. et al. Predictors of physical activity and barriers to exercise in nursing and medical students. J Adv Nurs. 2017; 73 (4): 917-929. DOI: 10.1111/jan.13181.

5. Dedov II, Mel'nichenko GA i dr. Ozhirenie i polovoe razvitie: epidemiologicheskoe issledovanie detey i podrostkov moskovskogo regiona. Ozhirenie i metabolizm. 2006. 3 (3): 1420. Russian.

6. Evdokimov VI, Gubina Ol i dr. Gigienicheskaya otsenka vliyaniya na zdorov'e studentov regional'nykh osobennostey ikh pitaniya. Gigiena i sanitariya. 2017; 96 (9): 909-912. Russian.

7. Baranov AA, Kuchma VR i dr. Otsenka kachestva okazaniya meditsinskoy pomoshchi obuchayushchimsya v obrazovatel'nykh organizatsiyakh. Vestnik Rossiyskoy akademii meditsinskikh nauk. 2017; 72 (3): 180-194. Russian.

8. Popov VI, Melikhova EP. Izuchenie i metodologiya issledovaniya kachestva zhizni studentov. Gigiena i sanitariya. 2016; 95 (9): 879-884. Russian.

9. Al-Drees A., Abdulghani $H$. et al. Physical activity and academic achievement among the medical students: A crosssectional study. Med Teach. 2016; 38 (1): 66-72. DOl: 10.3109/0142159X.2016.1142516.

10. Pivovarov YuP, Skoblina NA, Milushkina OYu i dr. Ispol'zovanie internet-oprosov $v$ otsenke osvedomlennosti ob osnovakh zdorovogo obraza zhizni. Sovremennye problemy zdravookhraneniya i meditsinskoy statistiki. 2020; (2): 398-413.

11. Baranov AA, Kuchma VR i dr. Provedenie monitoringa sostoyaniya zdorov'ya detey i podrostkov i organizatsiya ikh ozdorovleniya. M, 2006; $47 \mathrm{~s}$

12. Kuchma VR, Sukhareva LM i dr.] Universal'naya otsenka fizicheskogo razvitiya mladshikh shkol'nikov. M.: NTsZD, 2010; 34 s. Russian.

13. Kuchma VR, Sukhareva LM, Rapoport IK i dr. Rukovodstvo po shkol'noy meditsine. M, 2012; 215 s. Russian.
14. Kelley GA, Kelley KS. Effects of exercise in the treatment of overweight and obese children and adolescents: a systematic review of meta-analyses. J Obes. 2013; 12: 783103. DOI: 10.1155/2013/783103.

15. Diomidous M. Sleep and Motion Disorders of Physicians and Nurses Working in Hospitals Facing the Pandemic of COVID 19. Med Arch. 2020; 74 (3): 210-215. DOI: 10.5455/ medarh.2020.74.210-215.

16. Al-Drees A., Abdulghani $H$. et al. Physical activity and academic achievement among the medical students: A cross-sectional study. Med Teach. 2016; 38 (1): 66-72. DOI: 10.3109/0142159X.2016.1142516.

17. Milushkina OYu, Popov VI, Skoblina NA et al. The use of electronic devices by students, parents and teachers before and after the transition to distant learning. Bulletin of Russian State Medical University. 2020; 3: 77-82.

18. Markelova SV. Rol' roditeley, uchiteley, meditsinskikh rabotnikov v formirovanii znaniy, umeniy i navykov bezopasnogo ispol'zovaniya elektronnykh ustroystv starshimi shkol'nikami. Zdorov'e naseleniya i sreda obitaniya. 2020. 8(329): 50-57. Russian.

19. Milushkina OYu, Markelova SV, Skoblina NA et al. Evaluation of efficacy of providing hygiene education to schoolchildren and students in the process of development of the safe electronic device use skills. Bulletin of Russian State Medical University, 2020; 6: 141-146.

20. Nacar M, Baykan Z, Cetinkaya F et al. Health Promoting Lifestyle Behaviour in Medical Students: a Multicentre Study from Turkey. Asian Pacific Journal of Cancer Prevention. 2014; 15 (20): 89698974. DOI: 10.7314/APJCP.2014.15.20.8969.

21. Al-Kandari F, Vidal VL, Thomas D. Healthpromoting lifestyle and body mass index among college of nursing students in Kuwait: A correlational study. Nursing \& Health Sciences. 2008; (10): 4350. DOI: 10.1111/j.1442-2018.2007.00370.x.

22. Solhi M, Fard Azar FE, Abolghasemi $J$ et al. The effect of educational intervention on health-promoting lifestyle: Intervention mapping approach. Journal of Education and Health Promotion. 2020; (31): 9-196. DOI: 1270.4103/jehp.jehp_768_19.

23. Alzahrani $\mathrm{SH}$, Malik AA, Bashawri J et al. Health-promoting lifestyle profile and associated factors among medical students in a Saudi university. SAGE Open Medicine. 2019; (7): 1-7. DOI: 10.1177/2050312119838426.

24. Mašina T, Madžar T, Musil et al. Differences in health-promoting lifestyle profile among croatian medical students according to gender and year of study. Acta Clin Croat. 2017; (56): 84-91. DOI: 10.20471/acc.2017.56.01.13. 


\section{Литература}

1. Евдокимов В.И., Губина О.И. и др. Методика оценки психического здоровья и показатели адаптации студентов ВГМА. Системный анализ и управление в биомедицинских системах. 2005; 4 (4): 457-460.

2. Попов В.И., Либина И.И., Губина О.И. Проблемь совершенствования и оптимизации учебного процесса в медицинском вузе. Здоровье - основа человеческого потенциала - проблемы и пути их решения. 2010; 5 (1): 185-186.

3. Глыбочко П.В., Есауленко И.Э. и др. Здоровье студентов медицинских вузов России: проблемы и пути их решения. Сеченовский вестник. 2017; 2 (28): 4-11.

4. Blake H., Stanulewicz N. et al. Predictors of physical activity and barriers to exercise in nursing and medical students. J Adv Nurs 2017; 73 (4): 917-929. DOI: 10.1111/jan.13181.

5. Дедов И.И., Мельниченко Г.А. и др. Ожирение и половое развитие: эпидемиологическое исследование детей и подростков московского региона. Ожирение и метаболизм. 2006. 3 (3): 14-20.

6. Евдокимов В.И., Губина О.И. и др. Гигиеническая оценка влияния на здоровье студентов региональных особенностей их питания. Гигиена и санитария. 2017; 96 (9): 909-912.

7. Баранов А.А., Кучма В.Р. и др. Оценка качества оказания медицинской помощи обучающимся в образовательных организациях. Вестник Российской академии медицинских наук. 2017; 72 (3): 180-194.

8. Попов В.И., Мелихова Е.П. Изучение и методология исследования качества жизни студентов. Гигиена и санитария. 2016; 95 (9): 879-884.

9. Al-Drees $\mathrm{A}$, Abdulghani $\mathrm{H}$ et al. Physical activity and academic achievement among the medical students: A crosssectional study. Med Teach. 2016; 38 (1): 66-72. DOI: 10.3109/0142159X.2016.1142516.

10. Пивоваров Ю.П., Скоблина Н.А., Милушкина О.Ю. и др. Использование интернет-опросов в оценке осведомленности об основах здорового образа жизни. Современные проблемь здравоохранения и медицинской статистики. 2020; (2): 398-413.

11. Баранов А.А., Кучма В.Р. и др. Проведение мониторинга состояния здоровья детей и подростков и организация их оздоровления. М, 2006; 47 с.

12. Кучма В.Р., Сухарева Л.М. и др. Универсальная оценка физического развития младших школьников. М.: НЦЗД, 2010; 34 c.

13. Кучма В.Р., Сухарева Л.М., Рапопорт И.К. и др. Руководство по школьной медицине. М, 2012; 215 с.
14. Kelley GA, Kelley KS. Effects of exercise in the treatment of overweight and obese children and adolescents: a systematic review of meta-analyses. J Obes. 2013; 12: 783103. DOI: $10.1155 / 2013 / 783103$

15. Diomidous M. Sleep and Motion Disorders of Physicians and Nurses Working in Hospitals Facing the Pandemic of COVID 19. Med Arch. 2020; 74 (3): 210-215. DOI: 10.5455/ medarh.2020.74.210-215.

16. Al-Drees A., Abdulghani $\mathrm{H}$. et al. Physical activity and academic achievement among the medical students: A cross-sectional study. Med Teach. 2016; 38 (1): 66-72. DOI: 10.3109/0142159X.2016.1142516.

17. Milushkina OYu, Popov VI, Skoblina NA et al. The use of electronic devices by students, parents and teachers before and after the transition to distant learning. Bulletin of Russian State Medical University. 2020; 3: 77-82.

18. Маркелова СВ. Роль родителей, учителей, медицинских работников в формировании знаний, умений и навыков безопасного использования электронных устройств старшими школьниками. Здоровье населения и среда обитания. 2020; 8(329): 50-57.

19. Milushkina OYu., Markelova SV., Skoblina NA et al. Evaluation of efficacy of providing hygiene education to schoolchildren and students in the process of development of the safe electronic device use skills. Bulletin of Russian State Medical University, 2020; 6: 141-146.

20. Nacar M, Baykan Z, Cetinkaya F et al. Health Promoting Lifestyle Behaviour in Medical Students: a Multicentre Study from Turkey. Asian Pacific Journal of Cancer Prevention. 2014; 15 (20): 8969 8974. DOI: 10.7314/APJCP.2014.15.20.8969.

21. Al-Kandari F, Vidal VL, Thomas D. Healthpromoting lifestyle and body mass index among college of nursing students in Kuwait: A correlational study. Nursing \& Health Sciences. 2008; (10): 4350. DOI: 10.1111/j.1442-2018.2007.00370.x

22. Solhi M, Fard Azar FE, Abolghasemi $J$ et al. The effect of educational intervention on health-promoting lifestyle: Intervention mapping approach. Journal of Education and Health Promotion. 2020; (31): 9-196. DOI: 1270.4103/jehp.jehp_768_19.

23. Alzahrani SH, Malik AA, Bashawri J et al. Health-promoting lifestyle profile and associated factors among medical students in a Saudi university. SAGE Open Medicine. 2019; (7): 1-7. DOI: 10.1177/2050312119838426.

24. Mašina T, Madžar T, Musil V et al. Differences in health-promoting lifestyle profile among croatian medical students according to gender and year of study. Acta Clin Croat. 2017; (56): 84-91. DOI: 10.20471/acc.2017.56.01.13. 